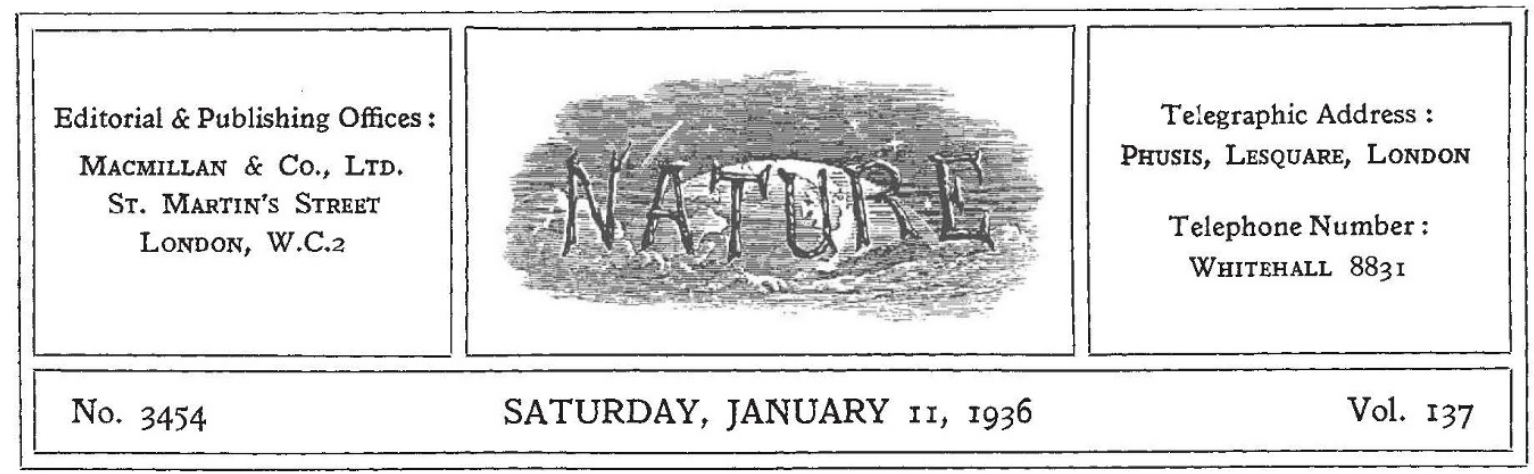

\title{
The Royal Commission on Safety in Mines
}

W HEN the King's Speech on the opening of Parliament on December 3 last stated that "the time has come when the existing provisions for the safety of workers in mines should be reviewed in the light of scientific knowledge", and that a Royal Commission would shortly be appointed "to inquire fully into this important matter", it might have been thought that it was intended to invoke the aid of science in such connexion. It therefore came as a shock to find that when, on December 18, the appointment of the promised Royal Commission was announced in Parliament, it contained no representative of science, but was composed of Lord Rockley (chairman), a county-court judge, the Chief Inspector of Mines, a former permanent Under-Secretary of State of the Home Office, a Labour M.P., the secretary of the Mineworkers' Federation, the president of the General Federation of Colliery Firemen's, Examiners' and Deputies' Association, and two colliery managers.

The terms of reference of the Commission are "to inquire whether the safety and health of mineworkers can be better ensured by extending or modifying the principles or general provisions of the Coal Mines Act, 1911, or the arrangement of the administration having regard to the changes that have taken place in organisation, methods of work and equipment since it became law, and the experience gained; and to make recom. mendations."

Although for many years past the death rate from accidents in mines in Great Britain (excluding big explosions of fire-damp or coal-dust) has been fairly constant between $0 \cdot 87$ and $1 \cdot 11$ per 1,000 persons employed, and British mines are among the safest in the world, much might still be done to reduce it. In a normal year, 'explosions', which in the popular mind loom largest among the perils of coal-mining, actually account for a minor proportion of the total deaths, the chief causes being 'falls of ground' and 'haulage accidents'. In exceptional years, however, like that of the great Senghenydd disaster (1913), 'explosions' may loom large in the death-dealing account; and it is of the utmost importance to safeguard the miner against them. Between 1920 and 1933 inclusive (omitting the great 'strike' years 1921 and 1926, and 1931, that of the Whitehaven explosion) the annual deaths from 'explosions' in British mines have been between 34 and 72 only, while those from 'falls of ground' have been between 454 and 607, and from 'haulage accidents' between 158 and 314 .

Undoubtedly the miner's calling is beset with great danger to life and limb; and it is the duty of the State, and all concerned with mines, to ensure that all available resources of science are mobilised in his defence. The appointment of a Royal Commission, without a single representative of science on it, to review in the light of scientific knowledge existing provisions for the safety of workers in mines, is an anachronism calling for speedy remedy. Surely engineering science can yet do much to reduce the present excessive deathroll from 'falls of ground' and 'haulage and shaft accidents'; while, as regards 'explosions', the prevention of which is largely a physico-chemical problem, science should eventually (if not soon) be able so to localise any explosion that its spreading throughout the whole (or main) workings of a coal-mine should become a thing of the past, and extensive colliery explosions should then cease. 
But even when science has done its all to minimise such perils, eternal vigilance will remain (as now) the prime condition of 'safety'; and the official inquiry into the recent Gresford disaster left an uneasy feeling that all is not as it should be.

Seeing that the Commission is charged with the duty of inquiring into the health, as well as the safety of mine-workers, the non-inclusion of any physiologist in its membership is to be severely criticised. The underground conditions of such hard and sustained manual work as miners have to perform call for greater scientific investigation and supervision than have yet been given to them ; and there are many problems in sanitation and nutrition upon which only physiologists are competent to pass judgment.

\section{Cultivation of the Unfit}

T ORD DAWSON OF PENN, like Sir Arthur 1 Keith, is one of the few scientific men who have the rare courage of forcing the public to listen to unpopular truth. Just as Sir Arthur Keith has repeatedly pointed out that war is not due to a perversion of human nature but is the inevitable result of increasing population and race pressure and is the means by which Nature decides which race shall "inherit the earth", so Lord Dawson, in his recent address to the York Medical Society entitled "Medical Science and Social Progress", has-not for the first timeraised the question of whether our philanthropic efforts to save the lives of all babies, however weakly, may not serve as actual hindrances to the future well-being and progress of our race. Lord Dawson asserts that, in the sixty-four years between 1870 and 1934, the infant death-rate has sunk from 156 to 60 per thousand, and of children under five years of age from 68 to 18 per thousand. The population during this time has increased by about fifty per cent, and the fact that there has not been a more spectacular increase is solely due to the concomitant fall in the birth-rate.

Amongst the lower species of animals, we may, without serious error, assume that the birthrate remains approximately constant; and the recurrent plagues of over-population are brought back to normal dimensions by the increase (1) in predatory animals, (2) in the incidence of disease. Only the most vigorous members of the species survive, and these are the worthy progenitors of the next generation. If this weeding out of the unfit is prevented, there follows a deterioration of the whole species. Two examples of this on a gigantic scale are sufficiently interesting to be recorded here. The first occurred in Switzerland : the second in New Zealand. The Swiss established a park for the preservation of the chamois, from which wolves were carefully excluded. As a result, more and more weakly and deformed specimens appeared amongst the stock until at last the Swiss introduced a certain proportion of wolves; these found in the weaker chamois an easy prey, and the surviving stock recovered its vigour and fine appearance. New Zealand has always been an ideal field for rearing mammals, because in it there are no indigenous predatory animals whatever. The Scottish settlers longed for the red deer of their native highlands, so these were introduced and let loose upon the New Zealand hills, where they flourished exceedingly. But soon the herds became polluted by misshapen specimens, and in the end wolves had to be imported to weed out the unfit.

Lord Dawson, therefore, poses the question: In adopting elaborate and costly social services in order to keep every baby alive, are we not preserving as progenitors of the next generation people who-morally, mentally, and physicallyare just as unfit as the deformed chamois and deer? But our sentimentalists tell us that the population is increasing ever more slowly and will soon be stationary; so that there is no occasion for worry. But the birth-rate is falling, if we may so phrase it, at the wrong end. In the middle of the nineteenth century the commercial and professional classes had large families, and the numerous children of clergymen were proverbial. The minimum size of family required to maintain a population constant is four ; for allowance has to be made for the sterility of some couples and the premature death of some children. The average size of family among both doctors and clergymen is now two, so that neither of these classes is maintaining itself by reproduction.

It would, however, be a libel to accuse the working-classes as a whole of over-breeding. When 